ROCZNIKI HUMANISTYCZNE

Volume 67, issue 1 - 2019

SELECTED PAPERS IN ENGLISH

DOI: http://dx.doi.org/10.18290/rh.2019.67.1-9en

BOŻENA KARWOWSKA

\title{
A BYSTANDER OR A (PASSIVE) WITNESS? \\ A FEW REMARKS ON THE CONSEQUENCES OF THE CHOICE OF TERMINOLOGY IN RESEARCH INTO THE SHOAH OR THE HOLOCAUST
}

The challenges that studies of the Holocaust face are connected with the fact that they are more and more clearly becoming a multidisciplinary, multicultural and international research field, one that is, however, connected with significantly different, and sometimes conflicting, national memories and approaches to the Second World War, as well as with different national models of teaching about the Holocaust. This is clearly indicated by the very debate, seemingly not so much about the subject of the research itself as with respect to the generally accepted (primarilyin the English-speaking countries) term used to denote the research area. The media presentations aimed at mass audiences that have been popularized since the 1970s, and especially the American television miniseries "Holocaust," give the mass extermination the dimension of a religious self-sacrifice, ${ }^{1}$ while at the same time limiting the research area exclusively to victims of Jewish origin, and more precisely to the population that was defined by the German Nazis as Jews. I will remind the reader here that Giorgio Agamben exhaustively explains his refusal to use the term "Holocaust" in his deliberations devoted to the Shoah ${ }^{2}$, referring to Primo Levi and Elie Wiesel's reluctance to use this

Dr. Bożena Karwowska-University of British Columbia, Vancouver, Faculty of Arts, Department of Central, Eastern, and Northern European Studies; Associate Professor; e-mail: bozena@mail.ubc.ca

The Polish version of the article was published in Roczniki Humanistyczne vol. 64, issue 1 (2016).

${ }^{1}$ Giorgio Agamben, Remnants of Auschwitz: The Witness and the Archive (New York: University of Michigan, 1999).

${ }^{2}$ Ibid. 
term $^{3}$. With all the differences between Agamben's philosophical approach and that of popular discourse formed by media representations of the Holocaust from the 1970s onward, these two approaches share the double-track perspective: on the one hand, of Jews and Germans, with the perspective of the victim changing under the influence of experience and, hence, according to Agamben's argument, that of being a witness and, on the other hand, of the perpetrator who is not transformed by such an experience and who, despite the killing, remains "an honest man" and a good German, and whose lack of transformation does not allow us to call him a witness.

In these divisions based on the binary opposition of good and evil there is no place for the figure of a bystander, a word which has become a catchword lately. It may be assumed, then, that both in the academically sublime philosophical discourse and in its simplified popular-media representation (copied by the largest and immensely influential group of educators-the guides of Holocaust tours) that is located at the other end of the intellectual spectrum, the triad victim-bystander-perpetrator does not have the same place as the binary division into a victim and a perpetrator. This is also confirmed by David Cesarani and Paul A. Levine's findings, who, in the Introduction to the volume of 'Bystanders' to the Holocaust: a Re-evaluation, ${ }^{4}$ remark that in the first twenty years after the war the discourse of victory completely overshadowed the issues connected with the position defined by the Englishlanguage term bystander. And Jorg Hackmann, ${ }^{5}$ referring to Tony Judt's observations contained in his essay The Past Is Another Country, ${ }^{6}$ remarks that in the postwar period both in Western and Eastern Europe "the common memory was closed in rather simple patterns of good and evil," the processes involved in it with the politics and the mentality of the Cold War period. In his opinion, when the West's attitude is best described by the notion of the appeasing "collective amnesia," the Eastern Block was charac-

\footnotetext{
${ }^{3}$ Agamben remarks that: "Not only does the term imply an unacceptable equation between crematoria and altars; it also continues a semantic heredity that is from its inception anti-Semitic" (ibid., 31).

4 'Bystanders' to the Holocaust: A Re-evaluation, ed. David Cesarani; Paul A. Levine (London-Portland: Routledge, 2002).

${ }^{5}$ Jörg Hackmann, "From National Victims to Transnational Bystanders? The Changing Commemoration of World War II in Central and Eastern Europe," Constellations 16, nr 1 (2009): $167-181$.

${ }^{6}$ Tony JudT, "The Past Is Another Country: Myth and Memory in Postwar Europe," in $\mathrm{Me}$ mory and Power in Post-War Europe. Studies in the Presence of the Past, ed. Jan-Werner Muller (Cambridge: Cambridge University Press, 2002), 157-183.

${ }^{7}$ Hackmann, "From National Victims," 168.
} 
terized by an amnesia imposed from above, not allowing anyone to join in the discussions arising from family stories on the social level and imposing from above the distinct roles of perpetrators (Germans), victims (Poles, Jews and citizens of the Soviet Union) and winners, with the Red Army at the head. Hackmann's and Judt's arguments are confirmed in the early postwar Polish literature, and especially in numerous camp memories, in Tadeusz Borowski's camp stories and in Zofia Nałkowska's Medallions. As Janna Michlic remarked, ${ }^{8}$ early postwar literary memoirs show Poles in the role of forced witnesses to the Holocaust of the Jews and opened up the debate that was stifled by the martyrological discourse in the Polish People's Republic period on the Poles' role and possible responsibility for the Nazi extermination of the Jews.

Hackmann connects the change in the approach to the history of the Holocaust and the war and stressing the role and responsibility of the population and nations put in the position of a bystander, with the fall of the Soviet block and with the democratic changes in Eastern Europe. It was these changes that made possible the social recollection of various stories kept in the family memory, and comparing them with the obligatory canon of the nationalized memory; the recollection led to negating and changing the obligatory discourses, and also to questioning the limitation of the Poles' role to national martyrdom and helping the Jews at the time of the Holocaust. As Hackmann stresses, in Poland the process started in the 1980s and the publication of Jan Józef Lipski's essay Two Homelands, Two Patriotisms and the television broadcast of Claude Lanzmann's Shoah played an exceptionally important role in it. Lanzmann's film made Poles face the question of Polish anti-Semitism and the role it played in the extermination of Jews.

On the other hand, reviewing the collection edited by David Cesarani and Paul Levine, Jack Nusan Porter ${ }^{9}$ emphasizes first of all the sense of pride distinctly felt by the Allies in postwar America in the victory achieved that for some time overshadowed, or even erased, the memory of the bitter war quarrels and misunderstandings. This finding confirms, as it were, the observation made by Alicja Iwańska, ${ }^{10}$ who, in her notes of the 1940 s, diagnosed

\footnotetext{
${ }^{8}$ Joanna Michlic, "Introduction," in The Neighbors Respond: The Controversy over the Jedwabne Massacre in Poland, ed. Antony Polonsky, Joanna B. Michlic (Princeton: Princeton University Press, 2003), 1-47.

9 Jack N. PORTER, "Reviews," Shofar 22, nr 2 (2004): 151-154.

${ }^{10}$ Alicja IwaŃska, Potyczki i przymierza. 1918-1985 (Skirmishes and Alliances. 1918-1985) (Warsaw: Gebethner, 1993).
} 
American pride in the victory as pride in the liberation of the Germans from the Nazis by the American army. Porter considers the trial of Adolf Eichmann in 1961 to be the moment when the liberation discourse was transformed into a discourse about the Holocaust, emphasizing that "for the first time the Jewish side of history was shown without entanglements in other issues, and sources, implementation and the experience of the victims of the «final solution» were focused on." ${ }^{11}$ What is of vital importance is that he implies in this way that, although history had been and may be told from various angles, the history of the Holocaust should be seen from the point of view of the victims, and the point of view of the victims is not so much represented as monopolized by Jews, ${ }^{12}$ and that Holocaust studies in their complete and pure shape should be perceived in just this way.

In his review Porter discusses not only the collection edited by Cesarani and Levine but also the book by Samantha Power, A Problem from Hell: America and the Age of Genocide devoted to the roles that the Western powers (playing the role of bystanders) played in modern genocides, and especially in Rwanda and the former Yugoslavia, just as in the North American discourse deliberations on the role of bystanders at the time of the Holocaust have been revived in the context of the re-examination of the attitudes adopted by the Western powers towards ethnic conflicts, and also (especially at the level of mass media) in the discourse on violence and environment pressure in coeval groups, and primarily the responsibilities that, by their passive behavior, bystanders have in all conflicts, including the phenomenon of violence among school children. Therefore, not only does the starting point, but also the contexts in which the issues connected with the position of bystanders, vary fundamentally, but this leads to the polarization of positions with, at the same time a clear trend (especially in the educational field) of simplified, binary thinking, of evaluating in terms of a division into good and evil as particularly understood.

Let us also note that the Polish term "Zagłada" does not fully correspond to the meaning of the notion of "Holocaust," for it does not limit the events

\footnotetext{
${ }^{11}$ PORTER, "Reviews," 153.

${ }^{12}$ It may be added here that identifying the victims with Jews at the beginning of the present millennium led Judith Butler to state, in a somewhat different context, that the position of the victim is a quickly changing one, and it is not monopolized by Jews. Cf. Judith BuTLER, No, it's not anti-Semitic, http://www.lrb.co.uk/v25/n16/judith-butler/no-its-not-anti-semitic [accessed: 13.10. 2016]. Albeit, which is one of the essential features of the Holocaust, in the context of German theory and practice and the Nazi policy of extermination, identifying Jews with the victims seems quite justified and understandable.
} 
it includes to the extermination of Jews. Moreover, the social acceptance of its use does not come from the media presentations, orientated toward the mass recipient, and so it does not transfer the simplifying model that makes it possible (if not, indeed, forces it) to create a story easy to tell and to understand. An English-language perpetrator is much different to the Polish "oprawca" ("slaughterer") and, first of all, signifies the one who causes events to happen and not their direct executor. It is not accidental that I am also using here the English concept of bystander that is bound to give rise to many questions about its equivalent in Polish. Discussing the difficulties involved in using this term, Janusz Woleński ${ }^{13}$ refers to the notion of "passive witness," showing in this way the fundamental difference between the use of this notion in the context of English-language (and especially North American) and Polish discussions of the "Zagłada" ("extermination") and the Holocaust (that is, the extermination of Jews). The English bystander is a person from the outside, one who "is standing beside," and in this way does not immediately participate in the event that is happening in his presence. Hence, the notion is at present used universally in relation to everyday conflicts at schools and above all it is in such a context that it is received in the extra-academic North American discourse connected with the Holocaust of Jews. Combined with the negative evaluation of the passive attitude, this bears fruit in the form of a reluctant attitude to those who, in the stories told by the Jewish survivors, "were standing beside," and who are shown as pigs in one of the most popular and influential representations of the extermination in the teaching about the Holocaust, the pictorial story Maus.

In this way, while the Germany liberated by the American army from the "Nazi occupation" has become a peculiar victim of Hitler's regime, the category of bystander is becoming a catchword in English-language (and not only) countries, and this category is divided into subgroups and signifies people who ever more frequently are being blamed for making the Holocaust possible (or for creating the favorable conditions for it). The common perception of the relationship victim-bystander-slaughterer comes from the comic book Maus that is popular with American school teachers; in this book, this triad gains the clear national designations Jews-Poles-Germans, and the Holocaust is shown as a cats' hunt for mice that is being watched by pigs. The differences in perceiving this triad (or, perhaps, rather not noticing

\footnotetext{
${ }^{13}$ Jan WoLEŃSKI, Executioners, Victims and Bystanders, in Holocaust. Voices of Scholars, ed. Jolanta Ambrosiewicz-Jakobs (Krakow: Centre for Holocaust Studies, Jagiellonian University, 2009), 267-278.
} 
it in the Polish Holocaust discourse) are well shown by comparing the Wikipedia entries in English and Polish. In the Polish-language version we read: "All the characters in the comic book are presented in the form of animals that metaphorically symbolize their nationalities. Jews are presented as mice doomed to extermination by cats that are the image of Germans. Poles are presented as pigs, Frenchmen as frogs, Americans as dogs, the British-fish, Gypsies-moths, and Swedes as deer," 14 whereas the English version says briefly: "The book represents Jews as mice and other Germans and Poles as cats and pigs." 15 It would be difficult to explain precisely the meaning of the word other in this sentence, but surely it separates the position of Jews from "others" while at the same time joining Poles and Germans. Cats and pigs, however, by no means represent the relationship between Germans and Poles during World War II and the German occupation. ${ }^{16}$

The differences in national education models, the differences in the canon of books about the Holocaust/Extermination, are clearly marked at the level of school education. While teaching about the Holocaust in Poland is based on general history, the American model of education is based on the individual story of a survivor, on a meeting with a local surviving witness who is best described by the notion "supertestes." As a result, a fairly interesting, but at the same time tricky and potentially dangerous, blend is formed. By writing memoirs and facing one's own trauma, a victim (supertesteswitness) creates a narration that allows reworking the past and working out a strategy that leads to the creation of the identity of a survivor. Writing memoirs (or a memoir story) is then a kind of therapeutic activity, although in American education programs it is simultaneously perceived as a model of teaching that reaches young people best. As a result, the figure of a bystander (a passive witness) is formed on the basis of Poles shown in the memories of authors who are not required to be responsible for the characters described, since their aim is the process of writing that allows the curing of

\footnotetext{
${ }^{14}$ https://pl.wikipedia.org/wiki/Maus._Opowie\%C5\%9B\%C4\%87_ocala\%82ego [accessed:

${ }^{15}$ Ibid.

${ }^{16}$ Let us once again emphasize the fact that Spiegelman's graphic story Maus nationalizes the characters in the triad. At the same time, Germans are separated from the sense of responsibility by the Nazis. Jews, who before the Holocaust were citizens of Poland, Czech Republic or Slovakia and often thought about themselves in this way, are given first of all a Jewish identity (and an identity that is ever more strongly associated with Israel). Put in the position of bystanders, that is of pigs, Poles cannot separate themselves from this part of society, to which the designation of the triad of Maus may directly refer.
} 5.12.2015]. 
the soul of the story-teller, giving back his own voice, giving him the right to his own story which is to remain subjective and does not have to take into consideration the rights of the characters described in it. ${ }^{17}$ In the education process (but also in the research process) those narrations often gain the status of a document, and so they create a popular version of the truth. With the now accepted definition of Holocaust studies as looking at history from the point of view of the victim, he who is in the position of a bystander is not defended by anything, primarily because this discourse depraves the bystander of the right to speak.

In the understanding that is close to the East European approach, a witness, and especially a so-called passive witness, is (I am referring here to Agamben, ${ }^{18}$ but also to Derrida ${ }^{19}$ ) a third person, in a way standing to the side, but above all a witness in the legal meaning of the word who, however, in the Holocaust discourse is put in a situation contrary to the definition of a testis, for it requires from him to actively take a definite position. Restoring the right to speak to this witness will allow us to discover the particular palimpsest that the events of 1939-1945 were, and hence it will be a challenge for Anglo-American Holocaust studies. Making them more historical will complicate the attempts to see the Holocaust as a model for talking about other genocides. We only have to ask the question whether the past that has been made unreal, that has been simplified and de-nationalised, can teach anybody anything? Could it be an element of teaching that will have an effect so that a similar history will never happen again?

\section{SELECTED BIBLIOGRAPHY}

Agamben, Giorgio. Remnants of Auschwitz: The Witness and the Archive. New York: University of Michigan, 1999.

'Bystanders' to the Holocaust: A Re-evaluation, ed. David Cesarani, Paul A. Levine. LondonPortland: Routledge, 2002.

\footnotetext{
${ }^{17}$ Sławomir Buryła writes interestingly about the effect of trauma on the perception of Poles' reaction to their Jewish co-citizens in the article "Proza współczesna o donosach i donosicielach" (Contemporary prose about denunciations and delators, in the same, Wokót Zagłady. Szkice o literaturze Holocaustu (Around the Holocaust. Sketches about the Holocaust Literature) (Krakow: Universitas, 2016), 114-139. On p. 127 Buryła writes: "The state of being trapped and of permanent fear must have lead to a distortion of reality, to its—unconscious—deformation."

${ }^{18}$ AgAmben, Remnants of Auschwitz.

${ }^{19}$ Jacques DerRIDA, “A Self-Unsealing Poetic Text," in Revenge of the Aesthetic: The Place of Literature in Theory Today, ed. Michael P. Clark (Berkeley: University of California Press, 2000), 180-207.
} 
DerRIDA, Jacques. "A Self-Unsealing Poetic Text." In Revenge of the Aesthetic: The Place of Literature in Theory Today, ed. Michael P. Clark, 180-207. Berkeley: University of California Press, 2000.

IwAŃSKA, Alicja. Potyczki i przymierza. 1918-1985 (Skirmishes and Alliances. 1918-1985). Warsaw: Gebethner, 1993.

JudT, Tony. "The Past Is Another Country: Myth and Memory in Postwar Europe." In Memory and Power in Post-War Europe. Studies in the Presence of the Past, ed. Jan-Werner Muller, 157-183. Cambridge: Cambridge University Press, 2002.

Michlic, Joanna. "Introduction." In The Neighbors Respond: The Controversy over the Jedwabne Massacre in Poland, ed. Antony Polonsky, Joanna B. Michlic, 1-47. Princeton: Princeton University Press, 2003.

PORTER, Jack N. "Reviews.” Shofar 22, nr 2 (2004): 151-154.

WolEŃSKI, Jan. Executioners, Victims and Bystanders. In Holocaust. Voices of Scholars, ed. Jolanta Ambrosiewicz-Jakobs, 267-278. Krakow: Centre for Holocaust Studies, Jagiellonian University, 2009.

\section{A BYSTANDER OR A (PASSIVE) WITNESS? A FEW REMARKS ON THE CONSEQUENCES OF THE CHOICE OF TERMINOLOGY IN SHOAH OR HOLOCAUST STUDIES}

\section{Summary}

The article is an attempt at an analysis of the usefulness of the concept of "bystander" that is becoming increasingly popular in social sciences, and in modern studies of the Shoah and the Holocaust. The author points to objective terminological dependencies, but she also takes into consideration the differences in the historical and cultural experience that require different perceptions of the role of witnesses in English language discourse and in the East European, and especially Polish, perspective.

Key words: bystander; Shoah; witness; sacrifice.

\section{Translated by Tadeusz Kartowicz.}

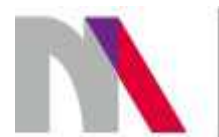

The preparation of the English version of Roczniki Humanistyczne and its publication in electronic databases was financed under contract no. 836/P-DUN/2018 from the resources of the Minister of Science and Higher Education for the popularization of science. 